\title{
Järkevin jalkinein henkilökohtaiseen ja yhteisölliseen queer-historiaan
}

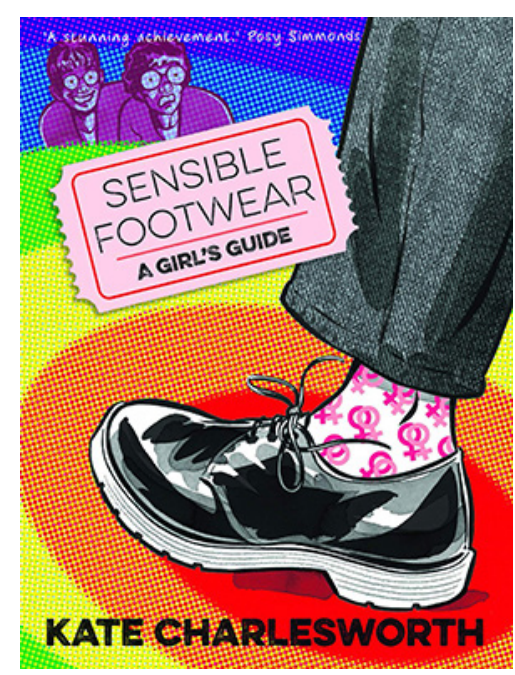

Kate Charlesworth. 2019. Sensible Footwear: A Girl's Guide. Myriad, 320 sivua.

Lesbon, feministin ja taiteilijan Kate Charlesworthin omaelämäkerrallinen sarjakuvateos Sensible Footwear: A Girl's Guide yhdistää henkilökohtaisen kasvutarinan yhteisölliseen queer-historian kertomukseen. Yli kolmesataasivuinen teos lähtee liikkeelle lomamatkalla esitetystä viattomasta kysymyksestä siitä, miten kauan kolme naista ovat tunteneet toisensa. Kertomus alkaa Katen lapsuudesta 1950-luvun Barnsleystä Pohjois-Englannissa ja kertoo tarinan, joka etenee enimmäkseen kronologisesti poikatytön lapsuusmuistoista taideopintoaikaan Manchesterissa ja aikuisen sarjakuvataiteilijan elämään Lontoossa ja myöhemmin Edinburghissa.
Sensible Footwear on mukaansatempaava ja vaikuttava kuvaus, joka yhdistää sarjakuvapiirroksiin lehtileikkeitä, lentolehtisiä sekä kuvia rintanapeista ja muista esineistä. Kuvat vaihtelevat lähes mustavalkoisista, vain korostevärillä väritetyistä, hyvin värikkäisiin ja kollaasimaisiin. Henkilökohtaiseen elämänhistoriaansa lomittaen Charlesworth kuvaa, arvioi ja kommentoi teoksessaan sitä massiivista muutosta, joka on tapahtunut yhden ihmisiän aikana suhtautumisessa seksuaalisuuden ja sukupuolen moninaisuuteen. Se ei ole kuitenkaan pelkkä edistyskertomus vaan muistuttaa myös muutoksen hauraudesta ja yhä uudelleen nousevasta vihasta.

Charlesworthin oman elämän ja hänen oman historiansa omaelämäkerrallisena kuvauksena kirja on koskettava ja samastuttava. Se kertoo kiinnostavasti oman lesbouden vähittäisestä rakentamisesta aikana, jolloin julkiset esikuvat ovat olemattomia tai vähäisiä. Lesboutta ei tarinassa havaita yhtäkkisen rakastumisen kautta, vaan se on hitaasti ja alkujaan melko teoreettisesti lukemisen ja tutkimisen kautta syntyvä ymmärrys. Samalla lesbous näyttäytyy tekemisenä ja jopa työnä, ei itsestään selvänä ja pysyvänä identiteettinä. Henkilökohtaisessa kasvukertomuksessa ovat läsnä perheessä ylisukupolvisesti välittyvät vaikenemiset ja toisten ohittamiset. Kirja kuvaa koskettavasti kipua siitä, kun kaikkein läheisimmissä suhteissa 
ei löydy riittävää ymmärrystä rakkauden ja elämän moninaisuudelle, mutta osoittaa samalla, ettei suhteiden säilyminen välttämättä edellytä toisten täyttä ymmärtämistä.

Populaarikulttuuri ja sen tulkitseminen kummastelevalla katseella nousee tarinassa alusta alkaen merkittävään asemaan, vaikka päähenkilön lapsuudessa positiivisia queereja esikuvia ei ollut tarjolla. Eri sukupolveen kuuluvalle suomalaislukijalle vain murto-osa lukuisista kulttuurisista viitteistä on tuttuja, mutta se ei haittaa kertomuksen seuraamista. Epäilemättä esimerkiksi brittiläistä Music Hall -teatteria tuntevalle viittaukset tiettyihin esityksiin ja myös tyylilajin hyödyntäminen sarjakuvan kerronnan keinona ovat vieläkin herkullisempia, mutta myös ilman tätä tietämystä musikaalikappaleiden tahdissa etenevät sarjakuvajaksot ovat vaikuttavia.

Henkilökohtaisen elämäntarinan lisäksi kirja on kuvaus kasvavasta ja monipuolistuvasta queer-yhteisöstä. Jo alkusivuilla Charlesworth esittää teoksen tavoitteeksi kertoa historia, joka olisi tärkeää tuntea edes oman yhteisön sisällä ja jonka avulla voisi taistella nousevaa suvaitsemattomuutta vastaan. Charlesworth tiedostaa kaikkien tarinoiden kertomisen mahdottomuuden ja paitsi pyytää anteeksi tarinasta puuttuvia näkökulmia myös huomauttaa, että se mikä on jäänyt nyt kertomatta, toimii lähtökohtana uusille tarinoille. Charleswothin mukaan moninaisuudestaan huolimatta LHBTIQ-yhteisö jakaa paljon yhteistä historiaa. Kirjan loppuviitteissä selitetään, että sarjakuvissa käytetään LGBT-kirjainyhdistelmää, vaikkei se olekaan aina täsmälleen ajanmukainen, myös siitä syystä, että se mahtuu hyvin puhekupliin.

Charlesworth kuvaa osuvasti, miten eri yhteiskuntaluokista ja eri elämänhistorioista tulevien lesbojen oli toisinaan täysin mahdotonta löytää yhteistä kieltä tai tavoittaa toistensa kokemuksia. Vaikka kirja kertoo nimenomaan lesboksi kasvamisesta ja lesboyhteisön osaksi tulemisesta, myös homomiesten kokemukset ovat siinä läsnä. Esimerkiksi AIDS-epidemia, jonka vaikutus homomiehiin oli erityisen murskaava, näkyy kertomuksessa yhtäältä kauhuna kuoleman ja lisääntyvän syrjinnän edessä mutta toisaalta myös yhteisöä vahvistava ja yhteenhitsaavana koettelemuksena. Charlesworth kuvaa Britannian oman kehotuskiellon, vuonna 1988 voimaan astuneen ja homoseksuaalisuudesta puhumista rajoittaneen lain, vaikutusta niin kaappeihin palauttamisessa kuin ennakkoluulojen ja suoranaisen vihan lisääntymisessä. Tältä osin Charlesworthin teos muistuttaa Matt Cookin (2017) kuvausta "sallivuuden käänteen” päättymisestä AIDS-epidemian seurauksena 1980-luvun lopulla. Yhteisten kamppailujen ohella Charlesworth valottaa myös yhteisöjen sisäisiä konflikteja. Hän onnistuu hyvin kuvatessaan homomiesten ja lesbonaisten välisiä jännitteitä, mutta esimerkiksi transihmisten kokemukset tai liikkeiden sisäinen rasismi eivät nouse kertomuksessa erityisen vahvasti esiin. Edistysaskeleet transihmisten asemassa samoin kuin rodullistettujen queer-ihmisten näkyvyys ovat kirjassa enemmänkin merkkejä muutoksesta, eivät osa yhteisöjen kamppailuja.

Charlesworthin kuvaama muutos muistuttaa seksuaalisuuden historian tutkija Jeffrey Weeksin - muutamaa vuotta Charlesworthia vanhemman britin - teoksessaan World We Have Won: Remaking of the Erotic and Intimate Life (2007) tarjoamaa analyysia "keskeneräisestä, mutta perustavasta" vallankumouksesta, joka on muuttanut suhtautumista seksuaalisuuteen toisen maailmansodan jälkeen. Weeksin tavoin myös Charlesworthin viesti on positiivinen: vaikka takaiskuja tapahtuu ja vaikka on selvää, että monet oikeudet edelleen puuttuvat, tapahtunut perustava mullistus on lisännyt ihmisten vapautta elää omaa elämäänsä haluamallaan tavalla. Kuten Weeks, myös Charlesworth keskittyy kuvauksessaan brittiläisiin ja laajemmin angloamerikkalaisiin kokemuksiin ja muu maailma tulee kertomukseen mukaan vasta sen loppupuolella, esimerkkinä siitä, miten voitetut oikeudet ovat paitsi hauraita myös edelleen puuttuvat monissa osin maailmaa.

$$
\text { (1) }
$$


Kate Charlesworthin sarjakuvateos on antoisaa luettavaa niin queer-historiasta kuin sarjakuvan kerronnallisista mahdollisuuksista kiinnostuneille.

Kirjaa voi suositella aivan erityisesti heille, jotka saattaisivat innostua

vastaavan historiallis-omaelämäkerrallisen teoksen toteuttamisesta jossain

toisessa maassa tai toisessa queer-yhteisössä - Charleswothin mukaan

hänen teokselleen kun ei ole luvassa jatko-osia (Hokkanen 2020).

\section{Kirjallisuus}

Cook, Matt. 2017. "AIDS, Mass Observation, and the Fate of the Permissive Turn". Journal of the History of Sexuality, 26(2): 239-272.

Hokkanen, Ahma. 2020. "Sateenkaarisaappaat". Sarjainfo (1): 28-30.

Weeks, Jeffrey. 2007. The world we have won: The remaking of erotic and intimate life. London, New York: Routledge. 